\title{
Pelatihan Hidup Mandiri sebagai Kunci Sukses Berkarya Pada Yayasan Komunitas Maestro 2012
}

\author{
Lia Kamelia ${ }^{1}$, Laini Rahayu Ningsih ${ }^{2}$, Reni Susilowati ${ }^{3}$, Ruri Anika ${ }^{4}$, Tri Murti ${ }^{5}$, Adji Widodo ${ }^{6 *}$ \\ 1,2,3,4,5 Mahasiswa Manajemen, Universitas Pamulang \\ ${ }^{6}$ Fakultas Ekonomi, Universitas Pamulang; ajiwi8@gmail.com
}

Received 09 Februari 2021| Revised 09 Maret 2021 | Accepted 22 April 2021

*Korespondensi Penulis

\begin{abstract}
Abstrak
Tujuan Pengabdian Kepada Masyarakat (PKM) Mahasiswa ini adalah untuk memberikan pengetahuan dan pemahaman kepada anggota Yayasan Komunitas Maestro2012 yang beralamat di Komplek Permata Pamulang, Ruko Blok I-2 No. 13 RT 001/ RW 03 Kelurahan Bakti Jaya, Kecamatan Setu, Kota Tangerang Selatan. Adapun Metode kegiatan ini adalah mendatangi Yayasan tersebut dan memberikan pelatihan dan diskusi mengenai kemandirian adalah salah satu kunci sukses berkarya. Hasil dari kegiatan tersebut adalah para peserta menjadi lebih mengerti makna kemandirian adalah salah satu kunci sukses berkarya. Yayasan Komunitas Maestro 2012 adalah salah satu bentuk kegiatan mandiri dalam berkarya dalam masyarakat. Ke depan diharapkan Komunitas ini akan lebih meningkatkan dalam pengelolaan usaha koperasi agar dapat memberikan kesejahteraan bagi anggotanya dan masyarakat.
\end{abstract}

Kata Kunci: Kemandirian; Berkarya

\begin{abstract}
The purpose of this Student Community Service (PKM) is to provide knowledge and understanding to members of the Maestro2012 Community Foundation who are located at Komplek Permata Pamulang, Ruko Blok I-2 No. 13 RT 001 / RW 03 Bakti Jaya Village, Setu District, South Tangerang City. The method of this activity is to visit the Foundation and provide training and discussion about independence is one of the keys to successful work. The result of this activity is that the participants understand better the meaning of independence is one of the keys to successful work. The 2012 Maestro Community Foundation is a form of independent activity in working in society. In the future, it is hoped that this Community Foundation will further improve the management of cooperative businesses in order to provide welfare for its members and society.
\end{abstract}

Keywords: Independence; Work

\section{PENDAHULUAN}

\section{Analisis Situasi Permasalahan}

Kemandirian merupakan sikap seseorang untuk bertindak bebas,melakukan sesuatu atas kesadaran diri sendiri, dapat menghadapi dan menyelesaikan sendiri masalah-masalah yang dihadapi tanpa tergantung bantuan orang lain dan bertanggung jawab terhadap segala keputusan yang diambil melalui pertimbangan yang rasional. Mereka yang lebih suka menggantungkan diri pada orang lain akan selalu bergantung pada orang lain

Untuk mencapai suatu kemandirian pada individu ataupun masyarakat baik itu pada aspek kemandirian ekonomi ataupun perilaku, untuk itu diperlukan suatu cara yang tepat. Dalam hal ini 
pengembangan sumber daya manusia (masyarakat) dirasakan perlu dilakukan melalui berbagai kegiatan pemberdayaan agar terciptanya sumber daya manusia yang berkualitas, tangguh, berwawasan dan mempunyai keunggulan serta keterampilan sehingga akan mencapai suatu kemandirian pada diri masyarakat itu sendiri..

Yayasan Komunitas Maestro 2012 adalah sebuah yayasan yang berdiri sejak tahun 2005 yang berkembang pesat. Hal ini terbukti salah satu programnya yaitu koperasi yang memiliki jumlah anggotanya terbesar se Tangerang Selatan, yaitu 1073. Tentu ini cukup fenomenal, sebagai sebuah koperasi yang berdomisili di sebuah ruko komplek perumahan dapat memiliki anggota yang sangat besar.

Oleh karena itu kami jadikan model pembelajaran sebagai bentuk kemandirian usaha di masyarakat sekitar yayasan berada.

\section{Permasalahan}

Anggota Yayasan Komunitas Maestro mempunyai peran, tugas dan tanggung jawab masing-masing atas tiap usahanya dan berperan aktif dalam upaya meningkatkan kualitas serta pengelolaan yang baik, Peran dan tanggung jawab masing-masing ini diperlukan penerapan sikap kemandirian dalam diri masing-masing anggota. Dalam Menghadapi kondisi global yang penuh persaingan, memang kemandirian merupakan salah satu modal yang ada pada diri individu, baik itu kemandirian bekerja maupun kemandirian belajar. Untuk mencapai kemandirian tentu saja tidak secara mendadak, tetapi perlu ditumbuhkan sejak dini di segala sisi. Dan harapan kami kegiatan ini dapat bermanfaat bagi masyarakat sekitar serta sebagai bentuk kontribusi mahasiswa dalam mendorong kemajuan bagi masyarakat.

\section{Tujuan Kegiatan}

1. Meningkatkan pemahaman lebih jauh kepada para peserta mengenai sifat kemandirian dan bentuk kemandirian usaha di masyarakat
2. Meningkatkan pengetahuan kepada para peserta tentang bagaimana melatih kebiasaan hidup mandiri sejak dini

3. Memberikan pengarahan dan pelatihan kepada peserta tentang menerapkan prilaku mandiri dalam berusaha

\section{Kerangka Pemecahan Masalah}

Alur kerja yang digunakan dalam menyelesaikan permasalahan yang dihadapi Masyarakat sekitar dan Anggota Komunitas Mestro seperti ditunjukkan pada gambar berikut:

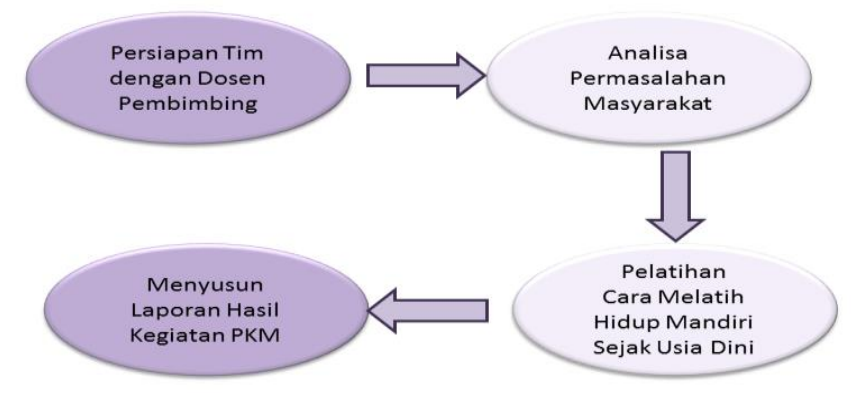

Gambar 1. Alur Pelatihan Hidup Mandiri

Berdasarkan alur pada gambar di atas, ada tiga tahapan yang harus dilakukan dalam program pembuatan jurnal PKM. Tiga tahapan yang dilakukan meliputi:

1. Tahap Analisa Permasalahan Masyarakat

2. Tahap Pelatihan Hidup Mandiri

3. Tahap Menyusun Laporan Hasil Kegiatan PKM

\section{Realisasi Pemecahan Masalah}

Realisasi pemecahan masalah dalam pelatihan hidup mandiri di Yayasan Komunitas Maestro, Kelurahan Baktijaya, Kecamatan Setu, Kota Tangerang Selatan. Dilaksanakan menggunakan tiga tahapan sebagai berikut:

\section{Tahap Pra Pelatihan}

Kegiatan pra pelatihan ini dilakukan dengan melakukan persiapan perlengkapan dan bahan materi yang ingin disampaikan dengan Dosen pembimbing kami yang bertujuan untuk mempersiapkan acara dan menggetahui 
permasalahan yang ada di lingkungan yayasan dan masyarakat sekitarnya dan untuk mencarikan solusi terbaik.

\section{Tahap Pelatihan}

Kegiatan pelatihan merupakan kegiatan sosialisasi dan penyampaian materi tentang tentang cara melatih hidup mandiri dan koperasi merupakan salah satu bentuk kemandirian usaha. Dengan pemaparan dan diskusi serta pelatihan memberi dorongan semangat masyarakat untuk menumbuhkan rasa bahwa pentingnya melatih hidup mandiri sejak usia dini dan mengenalkan lebih jauh atau lebih dalam tentang koperasi. Selain itu ada sesi tanya jawab peserta pelatihan bisa mengajukan pertanyaan sehingga kami bisa membantu memberi jawaban serta solusi.

3. Tahap Pasca Pelatihan

Pada tahap ini, fokus kegiatan yang dilakukan adalah menyusun laporan kegiatan serta memberikan saran untuk kegiatan selanjutnya.

\section{Kajian Pustaka \\ Kemandirian}

Istilah kemandirian berasal dari kata dasar diri, maka pembahasan mengenai kemandirian tidak akan lepas dari perkembangan diri itu sendiri. Kemandirian merupakan suatu sikap yang memungkinkan seseorang untuk bertindak bebas, melakukan sesuatu atas dorongan sendiri dan untuk kebutuhannya sendiri tanpa bantuan dari orang lain, maupun berfikir dan bertindak original/kreatif, dan penuh inisiatif, mampu mempengaruhi lingkungan, mempunyai rasa percaya diri dan memperoleh kepuasan dari usahanya. Adapun beberapa faktor yang dapat memengaruhi perkembangan kemandirian, yaitu :

(1) Pola asuh orang tua yang selalu menciptakan suasana aman dan nyaman serta menanamkan kemandirian sejak dini pada anak. (2) Sistem pendidikan disekolah yang menekankan pentingnya apresiasi, reward, dan penciptaan kompetisi positif yang akan memperlancar perkembangan kemandirian remaja. lingkungan masyarakat yang aman, menghargai ekspresi potensi remaja dalam bentuk berbagai kegiatan, dan tidak terlaku hierarkis akan merangsang dan mendorong perkembangan kemandirian remaja.

Tentunya sikap kemandirian dapat dilatih sedini mungkin, misalnya anak-anak diajarkan untuk memberekan mainannya kembali, toilet training dan kebiasaan sehari-hari lainnya. Memiliki sikap kemandirian akan mampu membawa seseorang dalam tangga kesuksesan, hal ini karena seseorang yang mandiri akan selalu berpikir dan berkarya dengan kemampuan yang ia miliki tanpa selalu mengharapkan sokongan penuh dari orang lain.

\section{Berkarya}

Berkarya merupakan pekerjaan seseorang dari hasil pemikiran kreatif diri sendiri yang tidak dapat dibatasi sampai menghasilkan sesuatu yang bermanfaat bagi semua orang Seseorang dapat berkarya secara bebas menurut imajinasinya masing-masing. Karya dapat berupa produk intelektual dan material. Produk intelektual dapat berupa novel, puisi, artikel, dan esai. Karya yang berupa material dapat diwujudkan berupa patung, kursi dan meja. Karya yang baik muncul dari pemikiran diri sendiri.

\section{METODE}

\section{Tempat Dan Waktu}

Tempat kegiatan pkm mahasiswa ini adalah di yayasan komunitas maestro 2012 ruko komplek permata pamulang, baktijaya, setu - tangerang selatan. Adapun pelaksanaan dilakukan selama 1 ( satu ) hari, yaitu tanggal 23 januari 2021. dengan rincian kegiatan sebagai berikut:

Tabel 1. Kegiatan PKM

\begin{tabular}{lllr}
\hline No & Kegiatan & Keterangan & \\
\hline 1 & Paparan/ & mahasiswa \& dosen \\
& presentasi materi & pembimbing & \\
\hline 2 & Diskusi/dialog & peserta, anggota \\
& & $\begin{array}{l}\text { yayasan \& masyarakat } \\
\text { sekitar }\end{array}$ & \\
& & &
\end{tabular}




\section{Metode Kegiatan}

Kegiatan PKM ini dilaksanakan dengan mendatangi yayasan tersebut dengan metode yang komunikatif dan atraktif. Memberikan pelatihan dan berdiskusi tentang cara melatih hidup mandiri dan koperasi merupakan salah satu bentuk kemandirian usaha kepada anggota yayasan dan masyarakat sekitar. Diawali dengan pemaparan materi dan kemudian diselingi dengan sesi tanya jawab mengenai tema yang disampaikan.

\section{HASIL DAN PEMBAHASAN}

\section{Koperasi Merupakan Bentuk Kemandirian Usaha Masyarakat}

Koperasi berdiri dengan prinsip kemandirian dengan tidak berada dibawah naungan organisasi lain dan tidak bergantung serta mengandalkan organisasilain, koperasi berdiri sendiri dengan membentuk struktur organisasi sendiri untuk mengelola dan menjalankan kegiatan usahanya dengan bertujuan meningkatkan kesejahteraan anggota dan masyarakat. Apa hubungan antara kemandirian dengan asas kekeluargaan pada koperasi. pertanyaan ini dilontarkan salah satu peserta pada saat berdiskusi, Asas kekeluargaan artinya, setiap anggota koperasi memiliki kesadaran untuk melakukan yang terbaik di setiap kegiatan koperasi, dan hal-hal yang dianggap berguna untuk semua anggota dalam koperasi tersebut kesadaran dari diri sendiri dilakukan dengan dasar prinsip kemandirian yaitu setiap anggota mempunyai peran, tugas dan tanggung jawab masing-masing atas setiap usaha itu sendiri, selain itu anggota koperasi di tuntut berperan secara aktif dalam upaya mempertingi kualitas dan bisa mengelola koperasi dan usaha itu sendiri

\section{Perubahan Bentuk Koperasi}

Dr. H. Adang Rukhiyat, MPd. Memberikan tanggapan mengenai presentasi yang telah kami lakukan beliau menjelaskan sudah ada perubahan dalam bentuk koperasi Sebelumnya
Sebelumnya Bentuk Koperasi menurut PP No.60 tahun 1959. Dalam PP No.60 tahun 1959 (pasal 13 bab IV) dikatakan bahwa "bentuk kopeasi ialah tingkat-tingkat koperasi yang didasarkan pada cara-cara pemusatan, penggabungan dan perindukannya." Dari ketentuan tersebut,maka didapat 4 bentuk koperasi,yaitu: 1.) Primer. 2) Pusat. 3). Gabungan. 4) Induk

Namun bentuk koperasi berubah menjadi hanya 2 bentuk sebagaimana dalam pasal $15 \mathrm{UU}$ No. 12 Tahun 1992 tentang perkoperasian disebutkan bahwa "koperasi dapat berbentuk koperasi primer atau koperasi sekunder." Dalam penjelasan pasal 15 UU No. 12 Tahun 1992 disebutkan bahwa "pengertian koperasi sekunder meliputi semua koperasi yang didirikan oleh dan beranggotakan koperasi primer dan atau koperasi sekunder, berdasarkan kesamaan kepentingan dan tujuan efisiensi, baik koperasi sejenis maupun berbeda jenis atau tingkatan. Koperasi sekunder dibentuk oleh sekurang-kurangnya tiga koperasi yang berbadan hukum baik primer maupun sekunder.

\section{Tingkat Pendidikan Orangtua Terhadap Karakter Anak}

Pola pikir orangtua dipengaruhi oleh latar belakang pendidikan orangtua sebagai pengalaman masa lalu. Menurut pemaparan oleh bapak H.Abdul Suyono yang merupakan salah satu pengawas Koperasi Maestro. Tingkat pendidikan orangtua di desa dan dikota berbeda dimana kebanyakan orang kota minimal berpendidikan dengan tamatan SMP sedangkan orang didesa dominan hanya bertamatan SD saja, Sementara itu prestasi intelektual yang rendah atau di bawah kemampuan disebabkan kurangnya stimulasi mental oleh orangtua di rumah, hal tersebut pada umumnya disebabkan karena rendahnya tingkat pendidikan yang dimiliki orang tua sehingga mereka tidak mengerti bagaimana membantu anak agar lebih berhasil. Dengan pemaparan dan diskusi serta pelatihan memberi dorongan masyarakat untuk menumbuhkan rasa bahwa pentingnya membangun karakter anak 
salah satunya adalah melatih hidup mandiri sejak usia dini. serta memberi penjelasan akan manfaat dari acara PKM ini, dan selanjutnya bisa lebih ditingkatkan lagi yakni dengan acara bakti social ditingkat RT dan RW sehingga dapat lebih mengena ke warga.

Berikut dokumentasi kegiatan pengabdian masyarakat:

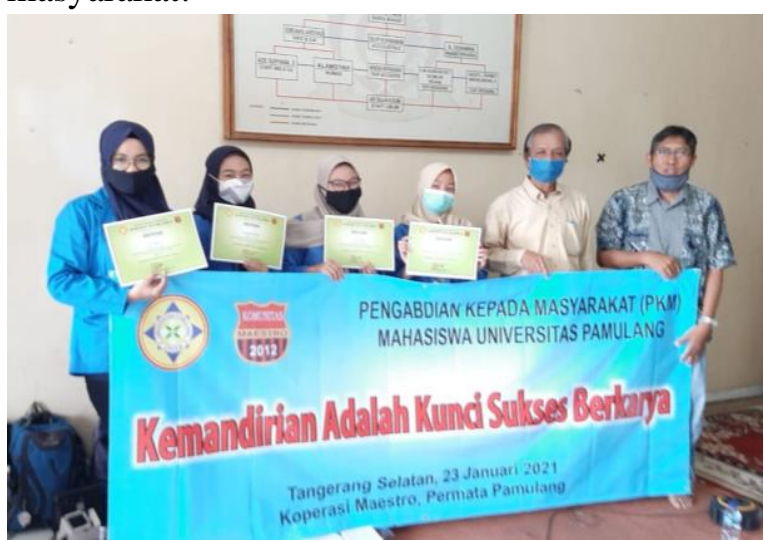

Gambar 1. Dokumentasi peserta PKM Mahasiswa

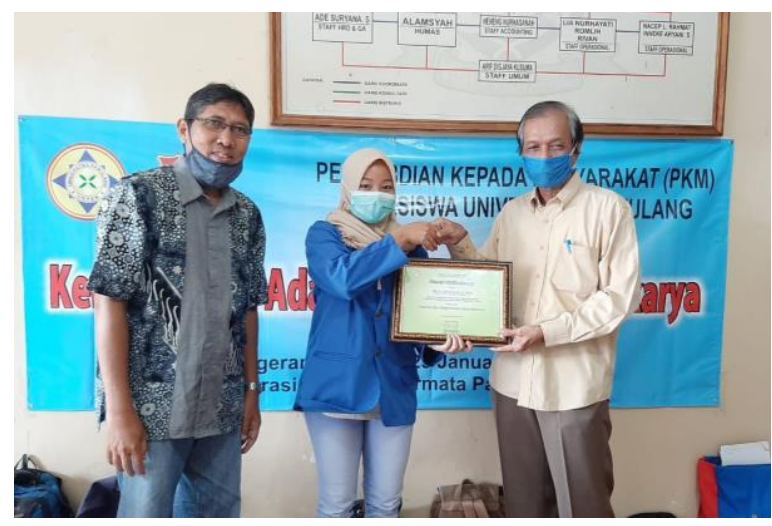

Gambar 2. Pemberian Cinderamata PKM

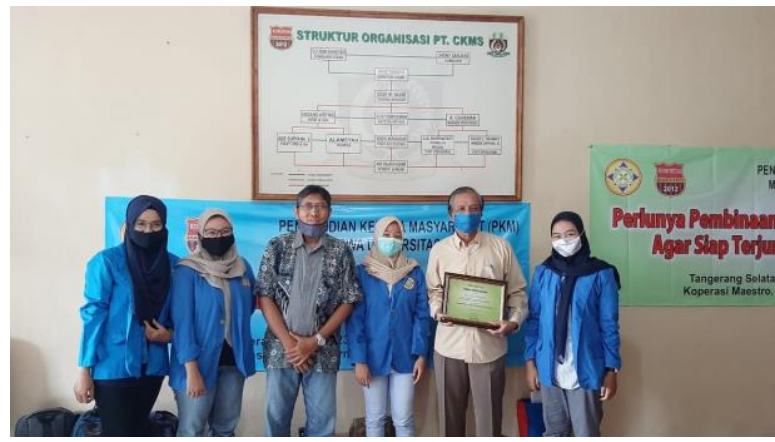

Gambar 3. Dokumentasi PKM Mahasiswa \& Dosen Pendamping

\section{SIMPULAN}

Kesimpulan

Pelaksanaan PKM telah dijalankan dengan baik dan tanpa halangan yang berarti. Dengan kerjasama tim yang baik dan peran serta aktif dalam kegiatan pengabdian ini maka semuanya berjalan sesuai yang diharapkan dan harapannya dapat memberikan manfaat bagi kami mahasiswa dan masyarakat sekitar. Dan dari paparan yang telah disampaikan terkait pelaksanaan kegiatan PKM Mahasiswa Prodi Manajemen Universitas Pamulang, yang bertempat di Komplek Permata Pamulang, Kelurahan Baktijaya, Kecamatan Setu - Tangerang Selatan, telah mendorong suasana kebersamaan dan semangat untuk bermasyarakat dan mulai latih hidup mandiri sejak usia dini

\section{Saran}

Perlu adanya pelatihan berkelanjutan bagi masyarakat yang lebih luas lagi tidak hanya pada lingkungan sekitar Yayasan Komunitas Maestro. Selanjutnya bisa lebih ditingkatkan lagi yakni dengan acara bakti social ditingkat RT dan RW sehingga dapat lebih mengena ke warga.

\section{DAFTAR PUSTAKA}

Adji Widodo dkk., 2020. Pengelolaan Organisasi Kepengurusan Yang Efektif Di TPA Putra Bani, Kel. Benda Baru, Pamulang. Jurnal Pengabdian Kepada MasyarakatAphelion Vol.01 No.01

Ali Dan Asrori, 2018. Psikologi Remaja: Perkembangan Peserta Didik. Jakarta: PT. Bumi Aksara.

Arifin, Johar, 2002. Manajemen Koperasi. Jakarta: Gramedia.

Haris Mudjiman, 2007. Belajar Mandiri (SelfMotivated Learning). Jawa Tengah: UNS Press.

Sujadi, 2003. Manajemen Koperasi. Surakarta: Fakultas Ekonomi UMS

Maya Sutra Wijaya, 2021. Membangun Budaya

Organisasi Dalam Bermasyarakat Di Yayasan Komunitas Maestro 2012, 
Kel.Bakti Jaya, Kec.Setu, Tangerang

Selatan, Banten. Universitas Pamulang.

Https://Kbbi.Web.Id/ (Diakses Pada 25 Januari

2021) 